\title{
Inositol phospholipid and phosphatidic acid metabolism in response to membrane receptor activation
}

By J. N. Hawthorne, Department of Biochemistry, University Hospital and Medical School, Nottingham $\mathrm{NG}_{7}{ }_{2} U \mathrm{H}$

The status of myo-inositol (Fig. I(a)) as a vitamin is uncertain since some human tissues can synthesize it from glucose-6-phosphate. Eagle et al. (1957), however, showed that it was an essential growth factor for many human cells in tissue culture. The concentration required for optimum growth was higher than would be expected of a typical vitamin, suggesting a metabolic role for inositol. It now seems clear that this role involves the phospholipids which contain inositol, phosphatidylinositol (PtdIns), phosphatidylinositol-4-phosphate (PtdIns4P; Fig. $\mathrm{I}(b))$ and phosphatidylinositol-4,5-bisphosphate (PtdIns $(4,5) \mathrm{P}_{2} ;$ Fig. I $\left.(c)\right)$.

For the nutritionist these phosphoinositides are of interest in at least three ways. First, their metabolism is linked to activation of many cell-surface receptors, most of which mobilize calcium (Michell, 1975). Second, very recent studies connect the phosphoinositides with control of cell proliferation through epidermal growth factor and with malignant transformation of cells. Third, these lipids are rich in arachidonic acid and in some cells this particular pool of the acid is used as a source of prostanoids. The present paper concentrates on the first two of these topics since they are attracting a good deal of attention and some controversy.

\section{Phosphoinositides and Ca mobilization}

Michell (1975) suggested that phosphoinositide-linked receptors were those which utilized $\mathrm{Ca}^{2+}$ as a 'second messenger' and he developed a theory linking

(a)

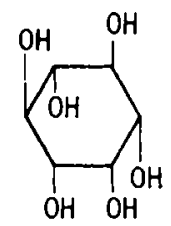

(b)

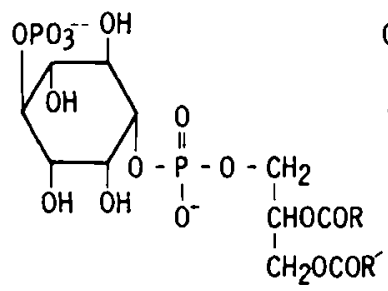

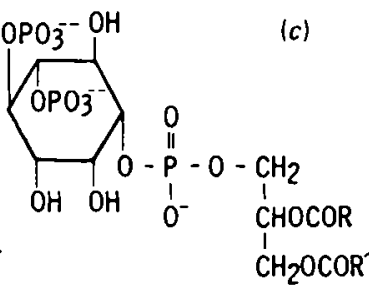

Fig. I(a), myo-Inositol; (b), phosphatidylinositol-4-phosphate; (c), phosphatidylinositol-4,5bisphosphate. 
hydrolysis of PtdIns with Ca gating. Occupation of the receptor was considered to activate the phospholipase $\mathrm{C}(E C$ 3.I.4.3) catalysing reaction (1):

$$
\text { PtdIns }+\mathrm{H}_{2} \mathrm{O} \longrightarrow \text { diacylglycerol }+ \text { D-inositol-I-phosphate }
$$

An enzyme of this type was first recorded from my laboratory (Kemp et al. 1959). It attacked both PtdIns and brain diphosphoinositide (now known to be a mixture of PtdIns4 $\mathrm{P}$ and $\left.\mathrm{PtdIns}(4,5) \mathrm{P}_{2}\right)$ and it had an absolute requirement for $\mathrm{Ca}^{2+}$. Subsequently, Dawson et al. (1971) showed that the initial product of the reaction was D-inositol-1,2-cyclic phosphate.

Evidence that loss of PtdIns occurs in response to muscarinic cholinergic stimulation was provided by Jones \& Michell (1974). An apparently more convincing demonstration of reaction ( 1 ), since inositol- $1,2-$-cyclic phosphate was detected, came from a study of 5-hydroxytryptamine action on blowfly salivary gland (Fain \& Berridge, r 979). The cyclic phosphate result has now been shown to be incorrect (Berridge et al. 1983).

The Michell (1975) PtdIns Ca-gating hypothesis has been criticized on several grounds (Hawthorne, 1982, 1983) but only two questions need concern us here: (a) Is PtdIns the correct phosphoinositide? (b) Is Ca-mobilization always associated with the phosphoinositide changes? The wider term Ca-mobilization is used to cover both entry of $\mathrm{Ca}$ from extracellular sources and its release from intracellular organelles.

\section{Receptor-linked metabolism of PtdIns or polyphosphoinositides?}

Polyphosphoinositide is the rather unsuitable generic name for PtdIns4 $\mathrm{P}$ or PtdIns $(4,5) \mathrm{P}_{2}$. The polyphosphoinositides are most abundant in myelin and are usually found in plasma membranes or related structures such as the chromaffin-granule membrane. For this reason they are better candidates for a response linked to cell-surface receptors than PtdIns, which occurs in most of the membranes of the cell. They are also particularly labile, a point that was made when the kinase-forming $\operatorname{PtdIns}(4,5) \mathrm{P}_{2}$ was first described (Kai et al. 1968), the relative rates of synthesis and hydrolysis being compared with those for acetylcholine. Because of this it was suggested by Kai et al. (1968) that $\operatorname{PtdIns}(4,5) \mathrm{P}_{2}$ had properties reminiscent of a chemical transmitter which was rapidly destroyed after receptor activation. Polyphosphoinositides may be hydrolysed by two active enzyme systems, a diesterase (reaction 2) which has been given much attention because of its link with surface receptors, and a monoesterase (reactions 3 and 4 ) which is largely ignored at present. It is not yet clear whether the same enzyme catalyses reactions $I$ and 2 :

$$
\begin{gathered}
\text { PtdIns }(4,5) \mathrm{P}_{2}+\mathrm{H}_{2} \mathrm{O} \longrightarrow \operatorname{Ins}(\mathrm{I}, 4,5) \mathrm{P}_{3}+\text { diacylglycerol } \\
\text { PtdIns }(4,5) \mathrm{P}_{2}+\mathrm{H}_{2} \mathrm{O} \longrightarrow \text { PtdIns } 4_{4} \mathrm{P}+\mathrm{P}_{\mathrm{i}} \\
\text { PtdIns } 4 \mathrm{P}+\mathrm{H}_{2} \mathrm{O} \longrightarrow \text { PtdIns }+\mathrm{P}_{\mathrm{i}}
\end{gathered}
$$


where $\operatorname{Ins}(1,4,5) P_{3}$ is inositol- $1,4,5$-trisphosphate and $P_{i}$ is inorganic phosphate. Chemical analysis of inositol lipids in tissues is difficult because of rapid breakdown post-mortem. Brain, nerve and adrenal medulla contain most polyphosphoinositides, but even there the three phosphoinositides account for only around $6 \%$ of total lipid-phosphorus. Other tissues contain much less polyphosphoinositide; for example, Downes \& Michell (1982) quote a total concentration of $20-40 \mathrm{nmol} / \mathrm{g}$ rat liver.

Some indication of polyphosphoinositide hydrolysis in response to acetylcholine was obtained first in brain synaptosomes (Durell et al. 1968; Schacht \& Agranoff, 1972). More direct evidence of receptor-linked polyphosphoinositide breakdown was provided by Abdel-Latif et al. (1977) for iris muscle and by Kirk et al. (1981) for hepatocytes. Until quite recently, however, most workers considered that PtdIns was the lipid which responded. The early evidence was based on increased labelling of this lipid with ${ }^{32} \mathrm{P}$ in response to an agonist such as acetylcholine. Better evidence is provided by loss of prelabelled phosphoinositide, since this is a more direct measurement of reactions I or 2. More recently, many workers have used the ion-exchange columns first described by Ellis et al. ( 1963$)$ to characterize the inositol phosphates produced in these reactions. The most recent theory of Berridge \& Irvine (reviewed by Berridge, 1984$)$ is that $\operatorname{Ins}(1,4,5) P_{3}$ released by reaction 2 is a second messenger mobilizing $\mathrm{Ca}$ from internal stores in cells such as hepatocytes, and pancreatic acinar cells. A cycle of reactions would need to be operating (Fig. 2).

According to this theory, the loss of PtdIns seen in response to agonists occurs only because it is required in the resynthesis of $\operatorname{PtdIns}(4,5) \mathrm{P}_{2}$. The evidence for this is that loss of labelled PtdIns $(4,5) \mathrm{P}_{2}$ is more rapid that loss of labelled PtdIns. At the present time, however, it is not easy to exclude the possibility that receptor activation causes PtdIns breakdown directly by reaction $\mathbf{I}$.

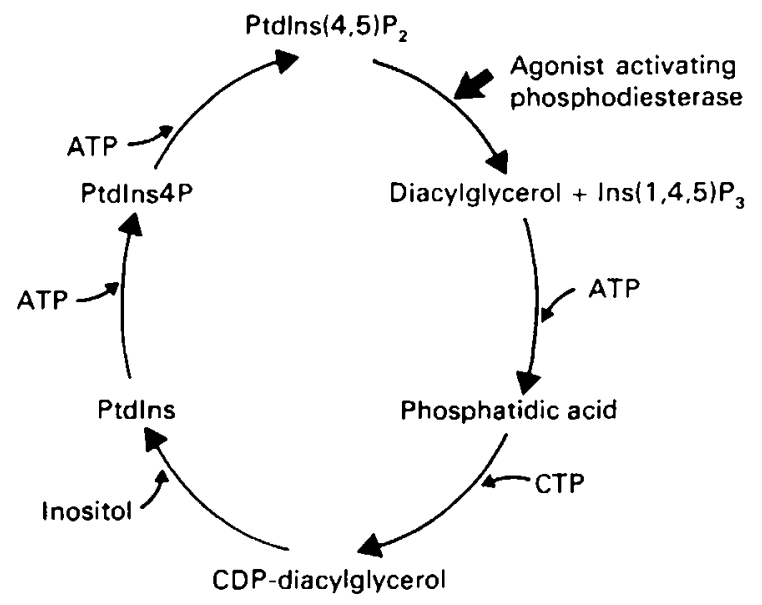

Fig. 2. Cycle of reactions involved in receptor-activated hydrolysis of phosphatidylinositol4,5-bisphosphate PtdIns(4,5) $\mathrm{P}_{2}$. PtdIns, phosphatidylinositol; PtdIns4 $\mathrm{P}$, phosphatidylinositol4-phosphate; Ins $(\mathrm{I}, 4,5) \mathrm{P}_{3}$, inositol- $\mathrm{r}, 4,5$-trisphosphate. 
Is Ca mobilization always associated with receptor-activated phosphoinositide breakdown?

Some acetylcholine receptors of the muscarinic type are inhibitory and their activation does not cause a rise in the intracellular concentration of Ca. Nevertheless, activation of such receptors leads to the typical phosphoinositide changes. Examples are certain muscarinic receptors of heart (Brown \& Brown, I983), those of the adrenal chromaffin cells (Swilem \& Hawthorne, 1984) and probably those of the cerebral cortex (Kendall \& Nahorski, 1984).

The most detailed information is available for bovine adrenal chromaffin cells in culture (Swilem \& Hawthorne, 1984). Stimulation of these cells by muscarinic drugs leads to breakdown of about $25 \%$ of the labelled pool of $\operatorname{PtdIns}(4,5) \mathrm{P}_{2}$ in $30 \mathrm{~s}$, yet there is no change in intracellular free $\mathrm{Ca}^{2+}$ as measured by the fluorescent indicator Quin-2. Activation of nicotinic receptors on the chromaffin cells causes entry of $\mathrm{Ca}^{2+}$ and promotes catecholamine secretion but there is no associated phosphoinositide effect. The muscarinic receptors appear to modulate catecholamine secretion (Swilem et al. ${ }_{1983}$ ) but their mechanism of action is not understood.

Another important point arises from the adrenal chromaffin-cell work and probably applies to most other systems in which receptors cause loss of PtdIns $(4,5) \mathrm{P}_{2}$. At the same time there is an equally-rapid loss of PtdIns4 $\mathrm{P}$ suggesting that the phosphodiesterase is also hydrolysing this lipid. The water-soluable product, inositol- 1,4 -bisphosphate $\left(\operatorname{Ins}(1,4) \mathrm{P}_{2}\right)$, is not able to mobilize $\mathrm{Ca}^{2+}$ (Streb et al. ${ }_{1983}$ ). It is thus difficult to see why this phosphate should be released. Another explanation is that PtdIns4 $\mathrm{P}$ is rapidly lost by phosphorylation to $\operatorname{PtdIns}(4,5) \mathrm{P}_{2}$ but this is unlikely in chromaffin cells, where the loss of PtdIns $4 \mathrm{P}$ is actually more rapid than that of $\operatorname{PtdIns}(4,5) \mathrm{P}_{2}$ with muscarinic agonists (Swilem \& Hawthorne, 1984).

At present therefore, Berridge's (1984) concept that $\operatorname{Ins}(1,4,5) P_{3}$ is a Camobilizing second messenger cannot explain all receptor-mediated phosphoinositide changes. Furthermore, if it is proved that $\operatorname{Ins}(1,4) P_{2}$ release accompanies Ins $(1,4,5) \mathrm{P}_{3}$ release, some role for the bisphosphate will be required before the theory is satisfactory.

\section{Phosphoinositides and the control of cell division}

Erwin Chargaff is best known for his work on DNA base-pairing, which laid the foundations of the double helix structure, but he also made a pioneering observation on myo-inositol and cell division (Chargaff et al. 1948) which is ignored in most reviews of this subject. Inositol was shown to block the anti-mitotic action of colchicine. The work has been confirmed for rat fibroblasts in culture and extended to rat intestinal mucosa (Lymberopoulos \& Hawthorne, 1980). Inositol is almost certainly involved here as a constituent of the phosphoinositides since mitogens which activate T-lymphocytes produce early effects on the metabolism of these lipids (Fisher \& Mueller, 1968). Changes in 


\section{Vol. 44 Nutritional aspects of membrane structure and function}

phosphoinositide metabolism was also seen in Rous sarcoma virus-transformed cells (Diringer \& Friis, 1977).

Nishizuka (1984) and his co-workers have described a protein kinase $\mathrm{C}$ which can be activated by the diacylglycerol released when phosphoinositides are hydrolysed in response to signals from surface receptors. Tumour-promoting phorbol esters can also activate this protein kinase $C$, although the substrates for the kinase are not yet identified.

The peptide hormone epidermal growth factor (EGF) causes increased labelling of PtdIns (Sawyer \& Cohen, I98r), and certain viral oncogenes produce a kinase similar to that of EGF receptor. This kinase was first thought to be a protein kinase but has now been shown to phosphorylate PtdIns (Macara et al. r984; Sugimoto et al. 1984).

Cell proliferation is considered to be controlled at least partly by entry of $\mathrm{Ca}^{2+}$ into the cytoplasm (Durham \& Walton, I982) so there may be a link between this process and the phosphoinositide changes. It is too soon to say exactly how the inositol lipids act. Berridge $\left(\mathrm{rg84}_{4}\right)$ has suggested that the breakdown of PtdIns $(4,5) \mathrm{P}_{2}$ is a key event, providing (a) inositol trisphosphate to mobilize $\mathrm{Ca}^{2+}$ from an intracellular store and (b) diacylglycerol to activate protein kinase $\mathrm{C}$ and in turn an $\mathrm{Na}^{+}-\mathrm{H}^{+}$exchanger which plays a role in growth control.

Whether or not these speculations prove correct, there is no doubt that the phosphoinositides play an important part in controlling the growth and division of cells and that this involves both protein and lipid phosphorylations.

\section{REFERENCES}

Abdel-Latif, A. A., Akhtar, R. A. \& Hawthorne, J. N. (1977). Biochemical foumal 162, 61-73.

Berridge, M. J. (1984). Biochemical fournal 220, 345-360.

Berridge, M. J., Dawson, R. M. C., Downes, C. P., Heslop, J. P. \& Irvine, R. F. (1983). Biochemical fournal $212,473-482$.

Brown, S. L. \& Brown, J. H. (1983). Molecular Pharmacology 24, 351-356.

Chargaff, E., Stewart, R. N. \& Magasanik, B. (1948). Science 108, 556-558.

Dawson, R. M. C., Freinkel, N., Jungalwala, F. B. \& Clarke, N. (1971). Biochemical fournal 122, $605-607$.

Diringer, H. \& Friis, R. R. (1977). Cancer Research 37, 2978-2984.

Downes, P. \& Michell, R. H. (1982). Cell Calcium 3, 467-502.

Durell, J., Sodd, M. A. \& Friedel, R. O. (1968). Life Sciences 7, 363-368.

Durham, A. C. H. \& Waiton, J. C. (1982). Bioscience Reports 2, I 5-30.

Eagle, H., Oyama, V. J., Levy, M. \& Freeman, A. E. (1957). Fournal of Biological Chemistry 226, $191-206$.

Ellis, R. J., Galliard, T. \& Hawthorne, J. N. (1963). Biochemical fournal 88, 125-131.

Fain, J. N. \& Berridge, M. J. (1979). Biochemical fournal x 78, 45-58.

Fisher, D. B. \& Mueller, G. C. (1968). Proceedings of the National Academy of Sciences, USA 60, I396-1402.

Hawthorne, J. N. (1982). Nature 295, 281-282.

Hawthorne, J. N. (1983). Bioscience Reports 3, 887-904.

Jones, L. M. \& Michell, R. H. (1974). Biochemical fournal 142, 583-590.

Kai, M., Salway, J. G. \& Hawthorne, J. N. (1 g68). Biochemical Youmal ro6, 791-801.

Kemp, P., Hubscher, G. \& Hawthorne, J. N. (1959). Biochimica et Biophysica Acta 31, 585-586.

Kendall, D. A. \& Nahorski, S. R. (1984). Fournal of Neurochemistry 42, 1388-1 394. 
Kirk, C. J., Creba, J. A., Downes, C. P. \& Michell, R. H. (1981). Biochemical Society Transactions 9. 377-379.

Lymberopoulos, G. \& Hawthorne, J. N. (1980). Experimental Cell Research 129, 409-414.

Macara, I. G., Marinetti, G. V. \& Balduzzi, P. C. (1984). Proceedings of the National Academy of Sciences, USA 81, 2728-2732.

Michell, R. H. (1975). Biochimica et Biophysica Acta 4r5, 81-147.

Nishizuka, Y. (1984). Nature 308, 693-698.

Sawyer, S. T. \& Cohen, S. (1981). Biochemistry 20, 6280-6286.

Schacht, J. \& Agranoff, B. W. (1972). Fournal of Biological Chemistry 247, 771-777.

Streb, H., Irvine, R. F., Berridge, M. J. \& Schulz, I. (1983). Nature 306, 67-69.

Sugimoto, Y., Whitman, M., Cantley, L. C. \& Erikson, R. L. (1984). Proceedings of the National Academy of Sciences, USA 81, $2117-2121$.

Swilem, A.-M. F. \& Hawthorne, J. N. (1984). Biochemical Society Transactions 13, 184-185.

Swilem, A.-M. F., Hawthorne, J. N. \& Azila, N. (1983). Biochemical Pharmacology 32, $3873-3874$. 